\title{
EDITORIAL
}

\section{Opening pressures in ARDS}

\author{
Claude Guérin ${ }^{1,2,3^{*}}$ and Laurent Papazian ${ }^{4}$
}

(c) 2017 Springer-Verlag Berlin Heidelberg and ESICM

We consider ourselves privileged to have been asked to compose an editorial about the latest research by a renowned and extremely creative group of investigators dealing with the critical lung opening pressures in ARDS patients [1].

The recommended practice of mechanical ventilation in ARDS is to provide lung protection and in particular to set tidal volume between 4 and $8 \mathrm{ml} / \mathrm{kg}$ predicted body weight and to limit airway plateau pressure below $28-30 \mathrm{~cm} \mathrm{H}_{2} \mathrm{O}$ [2].

Recent insights in four directions are highly relevant for a better use of the ventilator in ARDS patients. First, the homogeneity in the distribution of lung aeration loss/ tissue gain is better understood through the definition of patterns of lung recruitability over a 5- to $45-\mathrm{cm} \mathrm{H}_{2} \mathrm{O}$ airway pressure range [3] and the determination of opening and closing pressures that drive intra-tidal recruitment/ derecruitment over a much narrower range of pressure than the above [4]. Second, three ARDS stages of severity based on hypoxemia intensity have been defined [5], with the greater the hypoxemia, the higher the lung weight and the potential of recruitment. Henceforth, ventilator strategies have been proposed to match each ARDS stage [6], in particular, lowering tidal volume at every ARDS stage, setting low PEEP $\left(5-10 \mathrm{~cm} \mathrm{H}_{2} \mathrm{O}\right)$ in mild ARDS, middle PEEP $\left(10-15 \mathrm{~cm} \mathrm{H}_{2} \mathrm{O}\right)$ in moderate ARDS and high PEEP $\left(>15 \mathrm{~cm} \mathrm{H}_{2} \mathrm{O}\right)$ in severe ARDS. Third, in some ARDS patients, the precise assessment of lung mechanics requires the measurement of trans-pulmonary pressure [7]. Fourth, an alveolar pressure difference of $15 \mathrm{~cm} \mathrm{H}_{2} \mathrm{O}$ between inspiration and expiration (driving pressure) may be a safety threshold, better related to patient outcome than plateau pressure [8].

We know that the overall stress and strain (leading to baro-and volutrauma, respectively) must be minimized,

*Correspondence: claude.guerin@chu-lyon.fr

1 Réanimation Médicale Hôpital de la Croix Rousse, Lyon, France

Full author information is available at the end of the article and this can be done by lowering tidal volume. We know that cyclic opening and closing of the terminal respiratory units (atelectrauma) should be minimized, and that this can be done by using a sufficient PEEP level in order to maintain open the recruited lung mass gained at the end of inspiration. Evidence based on clinical trials suggests that atelectrauma, which is a very attractive concept, is likely less harmful than volutrauma. We know that lung homogenization needs to recruit either not or poorly aerated lung mass and that this process requires the delivery to the lung of pressures in the range of $45 \mathrm{~cm}$ $\mathrm{H}_{2} \mathrm{O}$ or even more [8], well above the recommended safety threshold. Furthermore, the response to a 5- to $45-\mathrm{cm} \mathrm{H}_{2} \mathrm{O}$ airway pressure range is not homogenous among ARDS patients nor through the entire lung in a dedicated ARDS patient [9]. However, whether this holds true over the whole spectrum of ARDS severity is not clear.

Taking previous considerations together, the ultimate goal of lung protective ventilation is both to preserve the baby lung and to increase the homogeneity in the distribution in lung aeration.

The paper by Cressoni et al. [1] aims at filling the gap of knowledge for three unsolved issues: (1) what is the amount of lung that can be recruited between 30 and $45 \mathrm{~cm} \mathrm{H}_{2} \mathrm{O}$ inspiration pressures in mild, moderate and severe ARDS? (2) Does PEEP of 5 or $15 \mathrm{~cm} \mathrm{H}_{2} \mathrm{O}$ induce the same amount of tidal recruitment/derecruitment in severe ARDS? And (3) does lung homogeneity change, and by how much and in which direction, in the most severe patients when increasing PEEP? The authors prospectively enrolled 33 consecutive ARDS patients in two centers and performed lung CT scans at different airway pressures. They analyzed the lung slices according to the classic quantitative approach. They found that: (1) between 30 and $45 \mathrm{~cm} \mathrm{H}_{2} \mathrm{O}$, the amount of recruited lung mass regularly and significantly increased from mild to severe ARDS with no difference between those treated

\section{Springer}




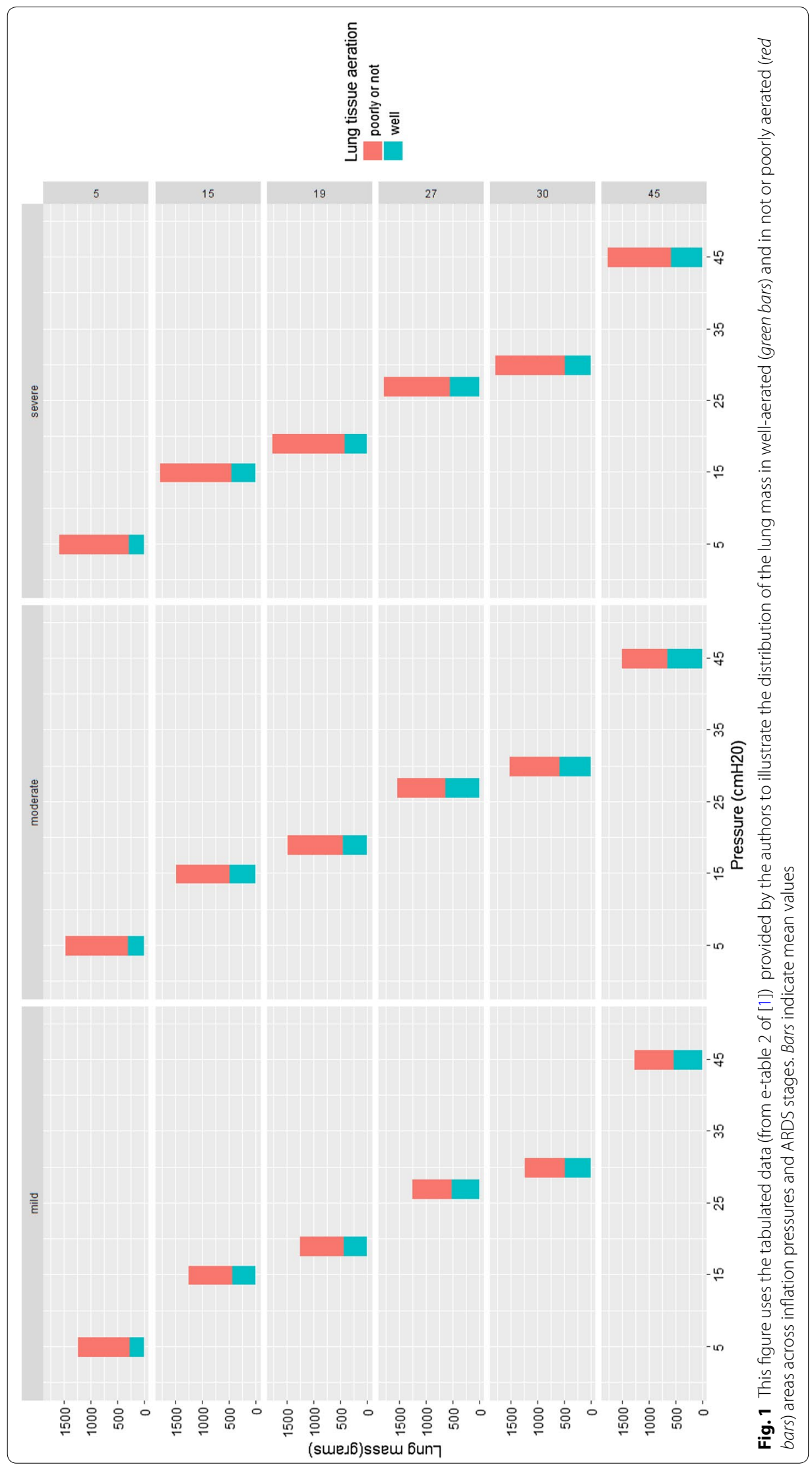


or not treated with ECMO; and (2) PEEP of 5 or $15 \mathrm{~cm}$ $\mathrm{H}_{2} \mathrm{O}$ induced the same amount of tidal recruitment/derecruitment in severe ARDS. One could have thought that severe ARDS patients exhibiting the highest potential of recruitment should receive higher PEEP than patients with less severe ARDS. Present results suggest this may not hold true, in line with a previous report of the same group showing that the level of PEEP was similar in patients with a low or a high potential of recruitment, whatever the method used to select PEEP [10]; and (3) increasing airway pressure enhanced lung homogeneity, but this increase was slight with increasing airway pressure in mild and moderate ARDS but not in severe ARDS patients (Fig. 1). This suggests that higher pressures are probably required for a more pronounced homogenization but at the price of a higher risk of hyperinflation.

Our attention was also drawn towards two insights and two limitations of the present study. The first unexpected result was that lung hyperinflation appeared really marginal. Indeed, it has been shown that 33\% of patients with ARDS receiving lung protective settings (tidal volume of $6 \mathrm{ml} / \mathrm{kg}$ and plateau pressure lower than $30 \mathrm{~cm} \mathrm{H}_{2} \mathrm{O}$ ) exhibited significant hyperinflation at the end of tidal inspiration [11]. This illustrates the fact that CT scans cannot determine hyperinflation accurately because the lung aeration loss is so important that a gas/tissue ratio of $9 / 1$ (or 10/1 depending on the thresholds used to define hyperinflation from Hounsfield units) cannot be reached. The second new insight was that lung properties were similar in severe ARDS treated or not treated with ECMO. This result could have implications for mechanical ventilation settings in ARDS patients under ECMO, However, these latter findings need to be confirmed. Indeed, the sample of patients may not be representative of the usual ARDS population, considering the rate of mortality, which was $80 \%$ in the severe group not treated with ECMO. This can be explained by the fact that the number of patients was reduced by tstudy design. Second, the tidal volume used was in the same range as that reported in the Lung Safe study [12], i.e. well above the $6 \mathrm{ml} / \mathrm{kg}$ predicted body weight, in particular in the severe ARDS group, and it was as high as $4.8 \mathrm{ml} / \mathrm{kg}$ in the ECMO group.

These points should be investigated in the future. Nevertheless, this elegant study [1] is an outstanding contribution in our understanding of the complex interplay between ARDS patients and mechanical ventilation.

\section{Compliance with ethical standards}

Conflicts of interest

The authors declare no conflict of interest regarding this editorial.

Received: 7 March 2017 Accepted: 8 March 2017

Published online: 20 March 2017

\section{References}

1. Cressoni M, Chiumello D, Algieri I, Brioni M, Chiurazzi C, Colombo A, Colombo A, Crimella F, Guanziroli M, Tomic I, Tonetti T, Vergani GL, Carlesso E, Gasparovic V, L Gattinoni. Opening pressures and atelectrauma in acute respiratory distress syndrome. Intensive Care Med. doi: 10.1007/ s00134-017-4754-8

2. ARDSnet (2000) Ventilation with lower tidal volumes as compared with traditional tidal volumes for acute lung injury and the acute respiratory distress syndrome. The acute respiratory distress syndrome network. N Engl J Med 342:1301-1308

3. Gattinoni L, Caironi P, Cressoni M, Chiumello D, Ranieri VM, Quintel M, Russo S, Patroniti N, Cornejo R, Bugedo G (2006) Lung recruitment in patients with the acute respiratory distress syndrome. N Engl J Med 354:1775-1786

4. Caironi P, Cressoni M, Chiumello D, Ranieri M, Quintel M, Russo SG, Cornejo R, Bugedo G, Carlesso E, Russo R, Caspani L, Gattinoni L (2010) Lung opening and closing during ventilation of acute respiratory distress syndrome. Am J Respir Crit Care Med 181:578-586

5. Force ADT, Ranieri VM, Rubenfeld GD, Thompson BT, Ferguson ND, Caldwell E, Fan E, Camporota L, Slutsky AS (2012) Acute respiratory distress syndrome: the Berlin definition. JAMA 307:2526-2533

6. Ferguson ND, Fan E, Camporota L, Antonelli M, Anzueto A, Beale R, Brochard L, Brower R, Esteban A, Gattinoni L, Rhodes A, Slutsky AS, Vincent JL, Rubenfeld GD, Thompson BT, Ranieri VM (2012) The Berlin definition of ARDS: an expanded rationale, justification, and supplementary material. Intensive Care Med 38:1573-1582

7. Chiumello D, Carlesso E, Cadringher P, Caironi P, Valenza F, Polli F, Tallarini F, Cozzi P, Cressoni M, Colombo A, Marini JJ, Gattinoni L (2008) Lung stress and strain during mechanical ventilation for acute respiratory distress syndrome. Am J Respir Crit Care Med 178:346-355

8. Amato MB, Meade MO, Slutsky AS, Brochard L, Costa EL, Schoenfeld DA, Stewart TE, Briel M, Talmor D, Mercat A, Richard JC, Carvalho CR, Brower RG (2015) Driving pressure and survival in the acute respiratory distress syndrome. N Engl J Med 372:747-755

9. Borges JB, Carvalho CR, Amato MB (2006) Lung recruitment in patients with ARDS. N Engl J Med 355:319-320 (author reply 321-312)

10. Cressoni M, Chiumello D, Carlesso E, Chiurazzi C, Amini M, Brioni M, Cadringher P, Quintel M, Gattinoni L (2014) Compressive forces and computed tomography-derived positive end-expiratory pressure in acute respiratory distress syndrome. Anesthesiology 121:572-581

11. Terragni PP, Rosboch G, Tealdi A, Corno E, Menaldo E, Davini O, Gandini G, Herrmann P, Mascia L, Quintel M, Slutsky AS, Gattinoni L, Ranieri VM (2007) Tidal hyperinflation during low tidal volume ventilation in acute respiratory distress syndrome. Am J Respir Crit Care Med 175:160-166

12. Bellani G, Laffey JG, Pham T, Fan E, Brochard L, Esteban A, Gattinoni L, van Haren F, Larsson A, McAuley DF, Ranieri M, Rubenfeld G, Thompson BT, Wrigge H, Slutsky AS, Pesenti A, Investigators LS, Group ET (2016) Epidemiology, Patterns of Care, and Mortality for Patients With Acute Respiratory Distress Syndrome in Intensive Care Units in 50 Countries. JAMA 315:788-800

\footnotetext{
Author details

${ }^{1}$ Réanimation Médicale Hôpital de la Croix Rousse, Lyon, France. ${ }^{2}$ Université de Lyon, Lyon, France. ${ }^{3}$ IMRB Equipe 13 INSERM 955, Créteil, France. ${ }^{4}$ AixMarseille University, APHM, URMITE UMR CNRS 7278, Hôpital Nord, Réanimation des Détresses Respiratoires et Infections Sévères, Marseille, France.
} 